\title{
The Joint Bussiness Group (KUBE) and Urban Poverty Reduction at Wirobrajan, Yogyakarta City: What and How
}

\author{
Erva HS Wifata ${ }^{a} *$ \\ ${ }^{a}$ Social Service Office of Yogyakarta Municipality, Yogyakarta, Indonesia
}

\section{ARTICLE INFORMATION}

\section{Article history:}

Data Submission: 28 August 2018

First Revision: 10 September 2018

Accepted: 13 December 2018

Available online: 17 December 2018

Keywords: Joint Business Group(KUBE), urban poverty, Yogyakarta City

\begin{abstract}
This study frames two research questions. Firstly, what is the present status of the implementation of the KUBE program in Wirobrajan, Yogyakarta. Secondly, what are the constraining factors on implementing the KUBE program? Result shows that the implementation of Joint Business Group (KUBE) Program in Wirobrajan Sub-District, Yogyakarta Municipality has not been well implemented. There are six constraint factors to contribute to the failure of the KUBE implementation in reducing the urban povertion in Yogyakarta City. Likewise, Of the 31 groups formed, only 17 active groups remain while 14 other groups are inactive or dispersed. This study suggests that in the selection of business types, they should be in accordance with the skills and abilities of the KUBE member and adjust those needs with the surrounding community's needs.
\end{abstract}

\section{INTISARI}

Studi ini membingkai dua pertanyaan penelitian. Pertama, bagaimana pelaksanaan program KUBE di Wirobrajan?. Kedua, apa faktor-faktor penghambat dalam melaksanakan program KUBE? Hasil penelitian menunjukkan bahwa pelaksanaan Program Kelompok Usaha Bersama (KUBE) di Kecamatan Wirobrajan belum dilaksanakan dengan baik. Ada enam faktor yang menyebabkan implementasi KUBE dalam mengurangi kemiskinan di Kota Yogyakarta belum berjalan dengan baik. Dari 31 kelompok yang terbentuk, hanya 17 kelompok yang aktif, sementara 14 kelompok lainnya bubar. Penelitian ini menunjukkan bahwa dalam pemilihan jenis bisnis: harus sesuai dengan keterampilan dan kemampuan anggota KUBE dan menyesuaikan kebutuhan tersebut dengan kebutuhan masyarakat sekitar.

2018 FIA UB. All rights reserved.

\section{Introduction}

The problem of poverty in Indonesia has caused major issues over the years and needs serious attention. Historically people have become impoverished not solely because of lack of food, but the impoverished are generally weak in their entrepreneurial endeavors and have limited accessibility to socio-cultural and economic activities, so they become left behind from other communities that have greater potential. For example, limits in all the following; infrastructures, educational facilities, health services and other limitations that would support their economic activities are lacking.

Statistically the number of the impoverished in Indonesia shows a declining trend. But the number of the impoverished is still high. In 2009 the number of the impoverished reached 32.53 million people. This

\footnotetext{
* Corresponding author. Tel.: +62-878-3855-5846; e-mail: erva_w@yahoo.co.id
} 
number continues to decline until in 2015 the impoverished in Indonesia was 28.59 million (BPS, 2015 ), just over a $11 \%$ of the total population. The graph below shows that the number of the impoverished in Indonesia tends to decline. This decline is clearly not separate from the various efforts that have been carried out by the government to tackle the poverty issue.

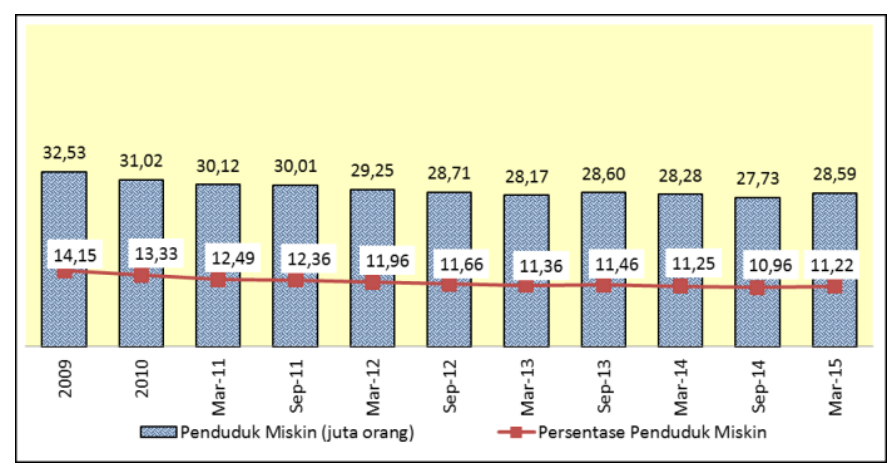

Figure 1 The Number of Poverty Stricken in Indonesia Source: Central Bureau Statistics (BPS), 2015

While table 1 shows that during the period of 20122016, the percentage of the impoverished in Yogyakarta is a positive reduction trend which is marked by a decrease in the number of the impoverished every year and the increase of percentage of population above the poverty line. In 2012, the number of the impoverished was about 37.4 thousand people or $9.38 \%$ of the total population of Yogyakarta. While in 2016, the percentage of the impoverished had decreased to $7.7 \%$ or equivalent to 32.06 thousand people.

Table 1 Poverty in Yogyakarta

\begin{tabular}{|l|r|r|r|r|r|}
\hline Population & \multicolumn{1}{|c|}{2012} & \multicolumn{1}{c|}{2013} & \multicolumn{1}{c|}{2014} & \multicolumn{1}{c|}{2015} & \multicolumn{1}{c|}{2016} \\
\cline { 2 - 6 } & 394,012 & 402,679 & 413,104 & 409,906 & 411,385 \\
\hline $\begin{array}{l}\text { Number the } \\
\text { impoverished } \\
\text { ('000) }\end{array}$ & 37.4 & 35.6 & 35.6 & 36 & 32.06 \\
\hline $\begin{array}{l}\text { Percentage of } \\
\text { the } \\
\text { impoverished }\end{array}$ & 9.38 & 8.82 & 8.67 & 8.75 & 7.7 \\
\hline
\end{tabular}

Source: Central Bureau Statistics of Yogyakarta City (BPS Yogyakarta), 2017

To cope with poverty in their area, the Yogyakarta Government has implemented several strategies in a poverty reduction policy. One such strategy is to empower the impoverished/ disadvantaged through economies, implemented under the impoverished Economic Empowerment program. With economic empowerment, it was expected that the overall society would be able to improve their life standard through production activity so that they can fulfill their needs. One form of economic empowerment was the establishment by the government the Productive Economic Enterprise (Usaha Ekonomi Produktif / UEP), where each disadvantaged individual is provided with capital assistance. Subsequently, the empowerment of groups of 10 or so, through the creation of the Joint Business Group (KUBE) program, these small groups formed a community to collectively engage in a business. KUBE is a group of disadvantaged, and impoverished families that is formed to grow and develop on their own initiative, interacting with each other, and residing in a certain area with the aim to increase their mutual productivity, promote harmonious social relations, meet the general needs of its members, solve the social problems they are experiencing and become a forum for a joint business development partnership (Social Minister Regulation No. 25/HUK/2013).

Since 2008, Yogyakarta has formed 468 enterprising groups. Each group consists of 10 impoverished members or so, so that at least 4,680 impoverished members have been empowered through the KUBE program. However, the extent to which the impact of the KUBE program has had on improving the welfare of its members has not been measured by the government. What has happened so far is the continuous growth of such groups every year. The growth of new groups each year can have both a positive and a negative impact. On the one hand, there will be many impoverished who are empowered through the formation of these groups. But on the other hand, if its effectiveness is not measured, this program will only cause the state budget to be in vain. Therefore, this study examines the implementation of poverty reduction through this program for the impoverished (kelompok usaha bersama fakir miskin/ kube-fm) in Wirobrajan, Yogyakarta. Accordingly, this study contributes to the existing literature on poverty alleviation in two ways. Firstly, this research explores how the implementation of the KUBE program in Wirobrajan, Yogyakarta improved the economic conditions of those in the program. Secondly, this review looks for any possible constraining factors on implementing the program so, in that case, in future the implementation of the KUBE program can be smoother, and more effective and targeted.

Many existing studies examined poverty and poverty reduction strategies in developing worlds (For example see Mensah and Benedict 2010; Bruton, Ketchen, Ireland 2013; Mahmood, Hussain and Matlay 2014) For instance, Mensah and Benedict (2010) argue that training of survivalist entrepreneurs and other poor persons with potential could open their eyes to opportunities around them which they could take advantage of to improve their economic situation and that of other poor persons in the area through job creation. Likewise, Bruton, Ketchen \& Ireland (2013) examine entrepreneurship as a solution to poverty. They examine the existing literature in a variety of business disciplines on poverty and found that entrepreneurs in poverty settings can create positive change-for their families, communities, and the broader society. In 
another case, Mahmood, Hussain, and Matlay (2014) find that access to finance is essential for female entrepreneurs in Pakistan and help them led enterprises in general and to poverty reduction among their families in particular.

Although many studies examined entrepreneurship as a strategy to reduce poverty in Indonesia, study about poverty within the context of the existence of Joint Business Group (Kelompok Usaha Bersama (KUBE)) is still rare (see Noor et al (2017), Endrawanti, and Wahyuningsih (2017), Tampubolon (2006); Marsoyo and Astuti (2014)).

For instance, Noor et al (2017), Endrawanti, and Wahyuningsih (2017) found the institutional of a local public sector in villages and bases (BKM) was ineffectively making bounded horizontally and vertically, and it was assumed as a promoted program and yet institutionalized in poverty reduction. Likewise, Utami (2016) examined the social-economy impact on poverty alleviation program through the joint business group (KUBE) in Bausasran, Yogyakarta. She found that KUBE has a significant socio-economic impact on the target group.

In other cases, Tampubolon et al (2006) explore about KUBE program in reducing poverty in Indonesia. According to Tampubolon et al (2006), Indonesian Ministry of Social Welfare implemented several empowerment programs to eradicate poverty. KUBE was one of these poverty eradication programs which consists of 3 (three) business categories, such as daily income, monthly income, and annual income earning activities. To overcome the group weaknesses through mutual and cooperative efforts, the KUBE dynamic associates with member characteristics, empowerment patterns, and the KUBE social environment. The community empowerment model through KUBE according to Tampubolon consists of 7 stages, namely: initial stage, program socialization stage, KUBE formation stage, implementation phase, business operational stage, business innovation stage, and evaluation stage. Likewise, Marsoyo and Astuti (2014) discuss about internal and external challenges of KUBE in addressing alleviating poverty by focusing on Home Based Entreprises (HBEs), such as: Household and shelter condition, relatively low income, and age of operator and business (internal challenges) and limited buyers, networking, competition, location and profitability, and dependency to government's assistance (external challenges).

This study aims to assess the impact of the Indonesian Poverty Alleviation Policy through the program for the impoverished/ KUBE FM (Program Kelompok Usaha Bersama Fakir Miskin). This study examines two points as follows. Firstly, this study investigates what the present status of the implementation of the KUBE program in Wirobrajan, Yogyakarta is. Secondly, this study elaborates what the constraining factors on implementing the KUBE program at Wirobrajan, Yogyakarta, are.

This paper examines the implementation of poverty reduction through joint business group program for the poor (Kelompok Usaha Bersama Fakir Miskin/ KUBEFM) in Yogyakarta City. By doing so, this study contributes to the existing literature on poverty alleviation in two ways. Firstly, this research explores how the implementation of KUBE-FM program in Yogyakarta City. Secondly, this study seeks constraining factors on implementing of the program so that in the future the implementation of KUBE program can be more effective and targeted.

This study focuses on Yogyakarta city because of several reasons, such follows. Firstly, the contrasting trend of datasets of poverty in Yogyakarta City. Data obtained from Central Bureau Statistics of Special Region of Yogyakarta in 2016 mentions that during the period of 2011-2015, the percentage of poor people in Yogyakarta City shows decreasing trend of the number of poor people every year however the percentage of population above the poverty line increases. In 2011, the population below the poverty line was about 38 thousand people or $9.62 \%$ of the total population of Yogyakarta City. While in 2015, the percentage of the population below the poverty line has decreased to $8.60 \%$ or equivalent to 36.6 thousand inhabitants.

Secondly, Yogyakarta mayor promotes several strategies in poverty reduction. To cope with poverty, the Yogyakarta City has implemented several strategies in poverty reduction policy. The policy pursued by the Yogyakarta City Government is fully supported by the Yogyakarta City Local Regulation no. 23 of 2009 on Poverty Reduction in Yogyakarta City. This Regulation as the legal basis to implement the regional action plan in poverty alleviation in Yogyakarta City. As a mandate from the Regional Regulation no. 23 of 2009, the Government of Yogyakarta City create the Regional Poverty Reduction Coordination Team (TKPKD) which is in charge of coordinating all Organization of Regional Devices and maintain synergy in poverty alleviation.

Also, this study has two strong significant research focus in term of that the impoverished in Yogyakarta have different characteristics from urban poverty in major cities like Jakarta and Surabaya. Firstly, the urbanization factor as the main factor affecting poverty in Jakarta and Surabaya does not affect Yogyakarta because most of the impoverished are indigenous people and immigrants who have long been a resident of the area. On contrary, demoghrapically, the population density of Yogyakarta is fluctuatively 11, 99 people per square kilometres to 12,077 people per square kilometres. This population density shows that in 
Yogyakarta, the the process of urbanization is not significantly taking place. The change in demographic composition of number of citizens shows a relatively stable. This situation indicate that changes of demographic composition only are the result of the movement of household family members. Secondly, Yogyakarta as a tourist destination contributes positively to the poverty structure because there is some work that can be carried out due to tourism and as a city that is the location of many well respected educational institutes.

\section{Theory}

Many existing scholars defines poverty in different approach (See Suliswanto and Wahyudi 2010; Chambers 1995; Sahdan 2005; and Astika 2010). According to Suliswanto and Wahyudi (2010), Poverty is a condition of unmet demand for basic or essential needs of human beings. The basic need includes the need for substitution, affection, security, cultural identity, protection, creativity, freedom of participation, and free time. With the existence of these basic needs, there are various types of poverty, including, but not limited to: a) substitutional poverty due to low income, unmet need for clothing, food, shelter and other basic needs; b) poverty protection due to the widespread culture of violence or inadequate protection of rights and basic needs; c) poverty affection due to forms of oppression, the pattern of exploitative relationships between humans and between humans and nature; d) poverty of understanding due to the low quality of education, in addition to quantity factors that are not able to meet the needs; e) poverty participation due to discrimination and marginalization of the people from the decision-making process; and f) identity poverty due to the imposition of foreign values on local culture that resulted in the destruction of existing socio-cultural values.

Chambers (1995) wrote that poverty is called absolute poverty as a living condition characterized by malnutrition, illiteracy, disease outbreaks, slums, high infant mortality rates, and low life expectancy. Poverty is complex and involves many interrelated factors and causes people in the impoverished category to remain in the trap of powerlessness. Interrelated factors such as low income, physical weakness, isolation or alienation, vulnerability, and lack of political power and bargaining are part of the condition.

In general, poverty is related to the ownership of a person or group to something, or the inability to get something as expected. The desire for something or the inability to get something is very specific in nature and it is closely related to the condition of the individual or group related, by which it will be associated, given the form of society and the standard of civilization and culture it has. This statement is in line with the definition of poverty according to Suparlan in Astika, expressed as a state of lack of property or valuables suffered by a person or group of people (Astika 2010).

Because of the lack of property or objects, a person or group of people may feel unable to finance the needs of his life properly. Such inability may be only at the level of cultural needs (customs, ceremonies, morals and ethics) or at the level of social needs (education, communication and interaction with others) or at the level of fulfillment of basic needs (food, clothing, residence or home, health and so on).

According to James C. Scott as quoted in an article by Sahdan (2005), in a mismanaged state, there is no greater problem than poverty. Poverty has made millions of children unable to access quality education, difficulties in financing health, lack of savings and lack of investment, lack of access to public services, lack of employment, lack of social security and protection of families, increased urbanization flows into the city, and the more severe, poverty puts millions of people in a difficult situation thereby unable to meet their needs of food, clothing and shelter. Poverty causes the public the willingness to sacrifice anything for a safety life.

In Indonesia, during the New Order era (Suharto era; 1966 - 1998), a national development policy was implemented from top down (centralistic), where society only become the object or target of development. This pattern resulted in a very high public dependence on the government as well as the disappearance of the community's ability to formulate needs and articulate its aspirations in development. Communities became helpless and accustomed to accepting programs from the top even though not always in according with their then needs.

Although the regime changed in 1998 to the reform regime, the patterns in poverty alleviation are still the same. Poverty alleviation programs have so far tended to focus on the delivery of social assistance to the impoverished, for example, rice for the impoverished, cash transfers impoverished and social safety net programs (JPS) for the impoverished. Such an effort alone is difficult to solve the problem of poverty that exists because the nature of the aid is not for empowerment, rather to cause dependency. These government-oriented programs of assistance can exacerbate the morale and behavior of the impoverished. The assistance program for the impoverished should be more focused on fostering a productive economic culture and capable of freeing permanent dependence of the population. In addition, these social assistance programs can also generate corruption during its distribution process. It is better if the funds are directly used for improving the quality of human resources, such as waivers for school fees including primary and junior 
high schools, and free medical expenses at community health centers (puskesmas).

In the context of poverty reduction efforts, it is necessary to change the development paradigm from top down to bottom up, by giving the role of the community as the main actor or the subject of development while the government as the facilitator. The bottom up process will make space for citizens or communities to participate in planning, determining needs, making decisions, implementation, and evaluating development.

In the context of governance, participation puts society in the right position. First, society is not a servant (client) but as a citizen. If the servant shows total obedience, then the concept of the people assumes that everyone is a whole person and has full rights to possess. Secondly, society is not able to govern but as a partner of government in managing governance and development. Third, participation is not a gift of government but as a citizen's right. Fourth, society is not just a passive object of government policy beneficiaries, but as an active actor or subject to policy.

Putting the position of society in the right position historically influences the direction of development and governance, although empirically it has not become a reality. The impoverished, for example, are now placed as development stakeholders. Participation is seen as a power to transform the social, economic and political relations that have been denied and thus create poverty. Now the poverty reduction agenda begins to put the impoverished in a respectable position, giving them space to develop local participation and initiatives, so that the concept of the impoverished as beneficiaries of the project is not very relevant to be discussed.

Participation is only possible to operate well, when starting from the awareness and active community initiative. This awareness and initiative will arise if the community has significant power and bargaining power in accessing, managing and utilizing the surrounding resources optimally. Participation is only possible when there is a balance between people's bargaining power/ bargaining position which is expected to become the main actor of development and government. In this context, empowerment is the key to success in increasing the capacity of the community to participate actively rather than just mobilize.

Community empowerment is a process whereby people - especially those with little access to development resources - are encouraged to increase their independence in developing their livelihoods. In principle, the community examines the main challenges of their development and then proposes activities designed to address this problem. This activity then becomes the basis of local, regional and even national programs. The main target of this approach is the marginalized group in society. However, this does not mean denying the participation of other groups. Community empowerment is a continuous cycle process, a participatory process in which community members work together in formal and informal groups to share knowledge and experience and strive towards shared goals. So, community empowerment is more a process than a blueprint approach.

Indonesia is in an excellent position to adopt the Grameen Bank program pioneered by Prof. Muhammad Yunus of Bangladesh. Because of the Grameen Bank's contribution to eradicate poverty in Bangladesh, Yunus was awarded the Nobel Peace Prize in 2006. The bank developed by Yunus specializes in serving the impoverished. Most importantly, participating members of the Bank program do not need to provide collateral. Tight facilitation is the key to the certainty of the loan repayment rate. Banks use a system of "solidarity groups". These small informal groups apply for joint loans and are the guarantor of credit repayment. Participating members together also maintain and empower the loan, so that it becomes a productive source for their lives. Above all, trust is central to the successful concept of empowering the impoverished through microcredit programs.

\section{Research Method}

To examine the how Yogyakarta city deal with urban poverty, this paper uses a single case study research with a qualitative approach. Yin (2003) defines a single case study as empirical inquiry that investigates a contemporary phenomenon within its real-life context (at one spesific area/ unit of analysis), escpecially when boundaries between phenomenon and context are not clearly evident. And, Qualitative approach is defined as a problem-solving procedure that is investigated by describing the state of the research object at this time based on the apparent or as it is. Also, Yin (2015) defines qualitative approach deals with more with words than with numbers and symbols. The purpose of qualitative research is to find the symptom in the field (fact finding) and find the relationship between the symptoms to be followed up with the analysis and interpretation of the symptoms data (Nazir, 2011:63). According to Nazir (2011:63), a qualitative method is a method in examining the status of a group of people, an object, a set of conditions, a system of thought or a class of events in the present. The purpose of this qualitative study is to make a systematic, factual and accurate description of the facts, traits, and relationships among the phenomena investigated.

The single case study and qualitative approach take place at Wirobrajan subdistrict, Yogyakarta. Actually, for comparative study, We launch the questioners to respondents among the 14 subdistricts. Interestingly, the questioner response rate at Wirobrajan subdistrict was 
the highest response rate among the 14 sub-districts of Yogyakarta City. Another interesting facts, this subdistrict experienced an increase in the number of the impoverished from 4,700 in 2013 to 5,200 in 2016.

Also, this single case study and qualitative approach aim to be a complementary the findings and to verify the credibility of the research. The Single case study and qualitative approach use the primary data and the secondary data.

The Primary data comes from data collected by researcher directly from the source, the outsiders, and key informants. The single case study and qualitative method operate some informal interviews with respondents, direct observation, and related document collection. Key informants who are strictedly selected and can be trusted. Data comes from 4 (three) selected key informants respectively as the KUBE FM members, the KUBE FM officers, Mentor and The Wirobrajan Subdistrict Officers. Detailly, all the KUBE members reside in Wirobrajan. In addition, interviews were also conducted with selected key informants in Wirobrajan, such as:

a) Head, Division of Social Advocation and Rehabilitation, responsible to understand and master all matters relating to the implementation of the KUBE Program in Yogyakarta;

b) Mentor who had a lot of experience in being part of KUBE; and

c) The KUBE program officers.

This primary data also includes interview scripts, field notes, videotapes, personal documents, notes or memos and other official documents The data can be obtained through sources related to the object of research including observation and in-depth interviews. Data sources that become observation objects are activities and conditions and phenomena that occur in the field. While the source of data that is the object of the interview is the informant who directly involved in the implementation of KUBE FM at Wirobrajan subdistrict. This data are generated in the form of descriptive data obtained from various sources such as: writings, words and official publications. The data comes from information in the form of documentation such as documents, regulation, archives, records, and official reports relating to research.

In other case, the secondary data also comes from reported by others outside the researcher. This data are generated in the form of descriptive data obtained from various sources such as: writings, words and documents. The data comes from information in the form of documentation such as documents, regulation, archives, records, and official reports relating to research. This secondary data are obtained from varied relevant agencies such as Central Bureau of Statistic of Yogyakarta City.
For instance, based on the secondary data obtained from the Social Service of Yogyakarta Municipality (Yogyakarta), sub-District of Wirobrajan(Wirobrajan), the KUBE cells in that area have been operational since 2008. There are 31 cells that have been formed since 2008. Each KUBE cell consists of 10 members and spread across three villages, namely Pakuncen Village (7 cells), Patangpuluhan Village (11cells) and Wirobrajan Village (13 cells).

\section{Results and Discussion}

\subsection{What Is KUBE in Yogyakarta?}

Based on the data obtained from the Social Service of Yogyakarta Municipality (Yogyakarta), sub-District of Wirobrajan(Wirobrajan), the KUBE cells in that area have been operational since 2008 . There are 31 cells that have been formed since 2008. Each KUBE cell consists of 10 members and spread across three villages, namely Pakuncen Village ( 7 cells), Patangpuluhan Village (11cells) and Wirobrajan Village (13 cells). Details of the KUBE program in Wirobrajan can be seen in the Table 2.

All these KUBE cells have received stimulant assistance in the form of cash, transferred to the bank the KUBE cell's designated bank, as previously informed each KUBE cell gets a stimulant assistance of Rp. 20,000,000 which is gradually made available by the bank. The stimulant assistance is divided into 2 stages aimed at stimulating group activity.

Table 2 KUBE at Wirobrajan Sub-District

\begin{tabular}{|c|c|c|c|}
\hline No & $\begin{array}{l}\text { Kelurahan/ } \\
\text { Village }\end{array}$ & Name of KUBE & $\begin{array}{c}\text { Year of } \\
\text { Establish-ment }\end{array}$ \\
\hline 1 & \multirow{7}{*}{ Pakuncen } & USEP KM Kel Pakuncen & 2009 \\
\hline 2 & & KUBE Barokah & 2008 \\
\hline 3 & & KUBE Fajar Pagi & 2009 \\
\hline 4 & & KUBE Sejahtera Mandiri I & 2010 \\
\hline 5 & & KUBE Maju Sejahtera 01 & 2010 \\
\hline 6 & & KUBE Maju Sejahtera 02 & 2010 \\
\hline 7 & & KUBE Maju Sejahtera 03 & 2010 \\
\hline 8 & \multirow{11}{*}{ Patangpuluhan } & $\begin{array}{l}\text { USEP KM Kel. } \\
\text { Patangpuluhan }\end{array}$ & 2009 \\
\hline 9 & & $\begin{array}{l}\text { KUBE Sejahtera XI Berhati } \\
\text { N KT } 46\end{array}$ & 2011 \\
\hline 10 & & $\begin{array}{l}\text { KUBE Sejahtera XI Berhati } \\
\text { N KT } 47\end{array}$ & 2011 \\
\hline 11 & & $\begin{array}{l}\text { KUBE Sejahtera XI Berhati } \\
\text { N KT } 48\end{array}$ & 2011 \\
\hline 12 & & $\begin{array}{l}\text { KUBE Sejahtera XI Berhati } \\
\text { N KT } 49\end{array}$ & 2011 \\
\hline 13 & & $\begin{array}{l}\text { KUBE Sejahtera XI Berhati } \\
\text { N KT } 50\end{array}$ & 2011 \\
\hline 14 & & $\begin{array}{l}\text { KUBE Sejahtera XI Berhati } \\
\text { N KT } 51\end{array}$ & 2011 \\
\hline 15 & & $\begin{array}{l}\text { KUBE Sejahtera XI Berhati } \\
\text { N KT } 52\end{array}$ & 2011 \\
\hline 16 & & $\begin{array}{l}\text { KUBE Sejahtera XI Berhati } \\
\text { N KT } 53\end{array}$ & 2011 \\
\hline 17 & & $\begin{array}{l}\text { KUBE Sejahtera XI Berhati } \\
\text { N KT } 54\end{array}$ & 2011 \\
\hline 18 & & $\begin{array}{l}\text { KUBE Sejahtera XI Berhati } \\
\text { N KT } 55\end{array}$ & 2011 \\
\hline 19 & & USEP KM Kel Wirobrajan & 2009 \\
\hline 20 & & KUBE Sejahtera VI/06 & 2010 \\
\hline
\end{tabular}




\begin{tabular}{|c|c|c|c|}
\hline No & $\begin{array}{l}\text { Kelurahan/ } \\
\text { Village }\end{array}$ & Name of KUBE & $\begin{array}{c}\text { Year of } \\
\text { Establish-ment }\end{array}$ \\
\hline 21 & \multirow{11}{*}{ Wirobrajan } & KUBE Sejahtera VI /07 & 2010 \\
\hline 22 & & KUBE Sejahtera VI /08 & 2010 \\
\hline 23 & & KUBE Sejahtera VI/ 09 & 2010 \\
\hline 24 & & KUBE Sejahtera VI /10 & 2010 \\
\hline 25 & & KUBE Mawar 01 & 2010 \\
\hline 26 & & KUBE Mawar 02 & 2010 \\
\hline 27 & & KUBE Wiro Sejahtera & 2011 \\
\hline 28 & & KUBE Maju Lancar & 2014 \\
\hline 29 & & KUBE Makmur Jaya & 2014 \\
\hline 30 & & KUBE Nurani & 2014 \\
\hline 31 & & KUBE Mandiri Sekar Arum & 2011 \\
\hline
\end{tabular}

Source: Analytical result, 2017

In Wirobrajan, from 2008 until now, $31 \mathrm{KUBE}$ cells have been established. The types of businesses run by each group are all the same, namely savings and loan businesses. According to the KUBE cells, the selection of this type of business is because of the ease of management, not creating or buying products to sell, so the funds remain intact because it is not used to buy production equipment, raw materials, etc. and existing target markets are members of the group itself. As time goes by, from 31 cells that have been formed only 17 remain today tin operation with 14 other cells disbanded. These later cells have disbanded because they are unable to manage their business properly. In addition, the group leaders were less able to maintain cohesiveness within their respective cells. Another reason is the lack of training on entrepreneurship and the number of Mentors with only 1 person, resulting in that these 14 groups are less able to solve internal problems between group members.

Even from the remaining 17 cells, not all have the same 10 members as at the beginning of establishment. There are between 5 to 10 people left in one group, for example. Members of the most of the cells experienced a lot of changes. At the beginning of the formation, these KUBE cells often consisted of the head of a family - usually male or husband. Today, however, many have been replaced by their wives so that the current members of KUBE cell in Wirobrajan are dominated by women.

KUBE cell is overseen by a Mentor who has been designated by the KUBE program officials so that businesses operated by the KUBE cell can develop optimally and the welfare of its members will thereby improve. In Wirobrajan, $31 \mathrm{KUBE}$ cells (although only 17 groups are still in operation) are also affiliated with one Mentor. In addition to the 31 cells, there are 23 others cells under the Mentors responsibility. These other groups are in other sub-districts (Tegalrejo Subdistrict). So, the number of cells assisted by the Mentor is 54 . With a total of 54 cells being assisted by one Mentor, the Mentor work load is nearly unbearable. This is not an ideal condition. Given this work overload, functions attached to this Mentor cannot be maximized.
Like the KUBE cell, the Mentor in Wirobrajan has not been provided adequate training. The lack of training has resulted in the Mentor lacking the ability to maximize her role in adequately assisting the KUBE cell.

\subsection{How Is KUBE in Yogyakarta Implemented?}

The KUBE program has been implemented in the Wirobrajan since 2008. Implementing this program is one of the steps in tackling poverty. The problem of poverty is one of the important issues that must be overcome by the government in accordance with the mandate of the 1945 Constitution of the Republic of Indonesia as stipulated in the Preamble to the 1945 Constitution, which is to promote the general welfare by empowering the community. The goal of empowerment is to improve the life of the Indonesian people and the community at large. In the long-term, the objectives are to reaffirm the wellbeing of it citizens by highlighting the creation of human qualities and the quality of advanced Indonesian society, modern and independent in the atmosphere of peace and prosperity, in the order of life of society, nation and state based on Pancasila (the official, foundational philosophical theory of the Indonesian state).

To find out how the implementation of the KUBE program is working, based on analytical theory, the author undertook the analysis using the theory of Mazmanian \& Sabatier. The theory states about the Framework for Implementation analysis is a model. This theory states that there are three groups of variables that influence the success of policy implementation, namely the characteristics of the problem (Trackability of the problem), characteristic of the policy (Ability of statute to structure implementation) and the environment of the policy (Non-Statutory Variables Affecting Implementation) (Mazmanian and Sabatier 1983).

Mazmanian and Sabatier in the framework of the Implementation Analysis Model, better known as the "Framework for Implementation Analysis", states that the policy characteristics becomes one of the elements that must be considered so that a policy can be implemented properly. The characteristics of this policy can be further detailed into seven points: clarity of policy content, how far the policy has theoretical support, the amount of financial resources allocation to the policy, the level of support from various stakeholders, clarity and consistency of the rules, the level of commitment to the policy objectives, and participation from outside parties who become the object of the policy.

The KUBE program, as a form of government policy in tackling poverty through community groups, has been included in several regulations, whether issued by the government or from related ministries in this case 
the Minister of Social Affairs. For example, the program has been written into several regulations, namely: (a) Government Regulation No. 42 of 1981 on Social Welfare Services for the impoverished; (b) Government Regulation No. 106 of 2000 on Management and Financial Accountability in the implementation of Deconcentration and Co-Administration; (c) Government Regulation No. 39 of 2002 on De-concentration Implementation; (d) Presidential Decree No. 124/2001 and No. 8 of 2002 on Poverty Alleviation Committee; (e) Decree of the Minister of Social Affairs No. 50/ PENGHUK/2002 on poverty reduction; and (f) Minister of Social Affairs Regulation No. 82/HUK/2005 on Organization and Work Procedure Ministry of Social Affairs.

The regulation remains downgraded as a guideline issued by the Ministry of Social Affairs. Nevertheless, these guidelines clearly state the definition of KUBE, the goals and objectives of the program and how these activities were developed. Empowerment of the program is an effort to provide resources, opportunities, knowledge and skills to a person or group of people so that they may determine their own future and to participate in influencing the lives of their communities. In its simplest form these programs provide the resources needed to start a business. In case of Yogyakarta, the assistance provided is capital assistance in the form of grant aid amounting to Rp. 20,000,000 per certified established KUBE cell.

\subsection{How Is KUBE in Yogyakarta Financed?}

Financial resources are a crucial factor for every social program. Each program also needs staff to support the program to do administrative and technical works, and monitor programs, all of which requires a budget. Each group of joint ventures are granted a grant of 20 million rupiah at the beginning of its establishment. These funds are provided free of charge by the social services as a form of grant aid support. Along the path to empowerment, KUBE cell members partake in training prior to being granted receipt of any funds. The training provided relates to the technical skills required in KUBE management. Assistance is provided in the form of funds under a bank saving account. Each member is authorized to use a portion of the grand aid in accordance with their proposal and which has been approved beforehand. Management is also important in the empowerment process. Management is carried out openly and the form of management is carried out by agreement among the participants of each cell -- cannot be carried out unilaterally by a board or chairman at the Program level.

Besides being funded by the Ministry of Social Affairs, additional funding can be sourced from KUBE cell members directly. The name of the grand fund is Social Welfare Fee (IKS). Sources of IKS are:

a) Members of the KUBE cell are provided at least Rp. 1,000 per day, with a share of $\mathrm{Rp} 500$, to be stored and managed by KUBE, and Rp. 500, to be stored and managed by the local Microfinance institution (LKM);

b) Productive economic business (UEP) Participants can receive a minimum of Rp. 1,000, - per day stored and managed by the local Microfinance institution (LKM); and

c) Microfinance institution (LKM) business profit percentage is $40 \%$ of the total LKM business profit.

IKS payments are made daily by KUBE cell members to the treasurer. The IKS funds kept and managed by the LKM are used with the provision that $40 \%$ is to be used for assistance for LKM/ KUBE/ UEP members with large assistance adjusted for the availability of funds. Thirty percent is used as additional funds for credit/ assistance channeled through KUBE or to UEP participants as loans. Another $30 \%$ is used for LKMS operational support.

\subsection{How Is The Commitment of Policy Makers?}

Mentors are not a complementary element in the empowerment process but perform many roles such as facilitators, motivators, educators, mediators, and others. One result of the survey showed that the absence of training of the Mentor is a key missing component. Mentors serve solely on their existing experience and abilities. If the training does not exist, perhaps the alternative can be hire someone who is more experienced or professionally stilled in the field.

The training Mentors receives is only at the beginning, soon after the cell is formed and includes such topics as basics bookkeeping and entrepreneurship. No advance training such as product design, packaging and marketing is subsequently carried out. This condition also experienced by the Mentor. In fact, the Mentor who is responsible to the KUBE cell at Wirobrajan did not receive any training at all, even though the local residents have limited ability and experience in the field of creating and financing a viable business.

Many cases of corruption occur in third world countries, and Indonesia is not corruption free especially given the low level of commitment of officials in carrying out the tasks of work or programs. The Ministry of Social Affairs as the organization that leads this program has delegated its authority to the related social offices that are likely to directly meet the residents in need. This commitment is implement in the form of mentoring and training to the KUBE cell members who are willing to join this activity. In the implementation of the KUBE program in Yogyakarta, 
commitment from the apparatus/ implementor is very high. This is indicated by the regular meeting between officers from the Social Agency of Yogyakarta with 10 mentors (total number of mentor in Yogyakarta City) which is held once a week to monitor KUBE development in each sub-district.

One of the elements in a well-executed policy implementation is the presence of outside group access to participate in policy implementation. A program that provides broad opportunities for people to engage in, will be relatively supportive rather than programs that do not involve the community. The community will feel alienated if they only "see" the program without getting involved in what exist in the vicinity/ area/ region.

The involvement of the Wirobrajan community is very low. This is since the existing activities are less sustainably socialized, and only certain parties are aware of the program. Presently, the social office is rather active without any feedback from the community. It took other processes to ensure that this was a program that could answer their questions all the time.

\subsection{Constraining Factors in Failuring Poverty Reduction by KUBE in Yogyakarta}

At Yogyakarta, especially for Wirobrajan, there are several constraining factors in the implementation of the KUBE program, namely:

a) The same type of business selected by several local KUBE cells. Each cell runs a savings and loan business. The type of business chosen has not been representative of the needs in the surrounding areas and access to the business is limited to cell members only, so the marketing and business development is very slow or not at all developed;

b) Group cohesiveness is not well established. Group cohesiveness is strongly influenced by the role of the group leader. The group leader has a major role in maintaining group cohesiveness. The group leader should have leadership skills and be able to motivate group members to be always active and motivated to attend every group meeting. In a group life, conflict due to dissent is common. The group leader must be able to provide a solution so that the conflicts that occur between members do not result in the dissolution of the group;

c) Ability and skill of cell members in operating the business is very low. Business management and bookkeeping ability that should be provided in a workshop or two in advance to run a saving and loan business have not been offered or mastered by some other means at all. This problem occurs because further education and training for cell members does not exist. Once a year KUBE cell leaders receive an invitation to attend a city-level forum where they can share their knowledge or experience on running their business. Nevertheless, the knowledge of how to organize and record finances the forum is not a learning opportunity, more of a 'show and tell' by what they have done. This is an example of bookkeeping (Figure 2):

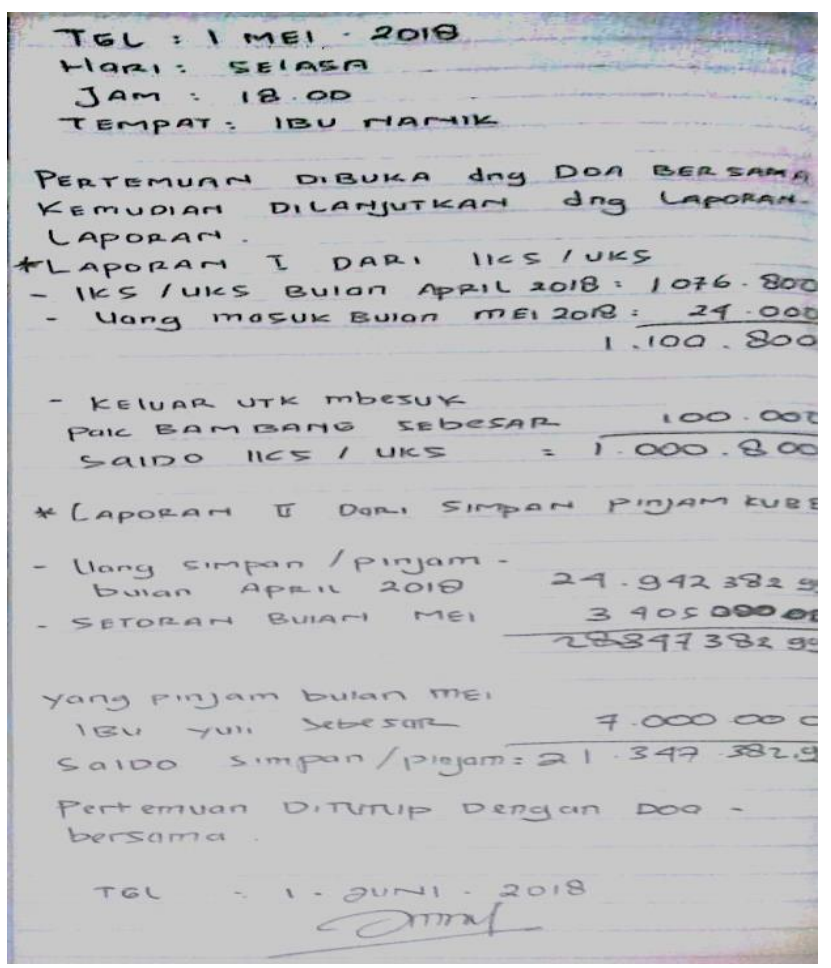

Figure 2 Bookkeeping record

Source: survey result, 2017

d) The number of Mentors, as an important part of the KUBE program, is very limited. With a total of 1 person for $31 \mathrm{KUBE}$ cells in the Wirobrajan area, the Mentor's burden becomes enormous. The result is that the Mentor is not providing the maximum output in carrying out his/ her tasks;

e) Training is one way to increase knowledge and improve skills rather forth rightfully. The more training undertaken, the more knowledge and skills will be transferred to all the KUBE members. The less training, the Mentors receive will be the less knowledge and skills the KUBE cells have. Under the KUBE program implantation, the training provided is not enough. For the Mentor in Wirobrajan he/she has not yet received any training. A possible snowball effect is being lost as the training of the Wirobrajan Mentor will lead to the transfer of knowledge to 31 KUBE cells with 10 members each for a total knowledge transfer to 310 recipients; and

f) Human resources or actors involved in the implementation of the KUBE program are very limited and do not had sufficient experience and skills. The limited number of personnel in managing the KUBE program results in the existing personnel having to handle many groups at one time. Until 
now, this problem is still faced by the Yogyakarta Municipality Social Service department when implementing the KUBE program. The number of apparatus (civil servant) handling the KUBE program are only is 5 so the sustainability supervision of the group in Yogyakarta is not having the maximum positive affect.

\section{Conclusion}

The KUBE program is one of the Ministry of Social Affair's strategies to empower impoverished families to increase their family income through productive economic activities and the establishment of microfinance institutions. The program is implemented with the provision of venture capital, business training, skills improvement, business motivation guidance and mentoring. The KUBE cells are also provided with Mentor, so that the business operated by the KUBE cell can develop optimally, and the welfare of its members will thereby improve. The presence of the KUBE Mentor is one of the factors that determine the success of the poverty alleviation policy through the Joint Business Group (KUBE) program approach. It has a very strategic role, as a resource body, and together with the Mentor, as a facilitator for the empowerment of the impoverished families. Of course, to be able to carry out such a heavy task, the Mentor must have adequate knowledge and ability.

The KUBE program as one of the strategies in poverty alleviation in Yogyakarta has been operating for almost 10 years. The implementation of the program in Yogyakarta began in 2008. The number of KUBEs has increased to 468 cells in 2016. In general, the number of the impoverished in Yogyakarta has decreased, but in Wirobrajan the number in the last three years has increased.

In Wirobrajan, the number of KUBE cells that were formed since 2008 was 31 cells. Of the 31 cells formed, only 17 cells are still active while 14 cells are no longer active, or in percentage $45 \%$ failed and $55 \%$ still are in operational. For almost a decade, this $45 \%$ failure rate continues to be a high number. So, it can be said that the implementation of the KUBE program in Wirobrajan has not contributed to the desired level of improvement for the residents' welfare in the region.

There are several constraining factors in the implementation process of the KUBE program in Wirobrajan, i.e.:

a) There is no variation in the type of business operated by the KUBE cells and the type of business also has not been to be established does not concern itself with the needs of the surrounding environment;

b) The level of cohesiveness is still low;

c) Lack of ability and skill of group members in operating the business; d) Limited number of Mentors; and

e) There is a lack of training and skills possessed by all Mentors. With regards to the Mentor in Wirobrajan, she has not received any training;

The number of administrative officials handling the KUBE program is very limited so that the supervision on the sustainability of the group that has been/will be formed is not at the maximal.

Based on the results obtained, the author provides the following suggestions:

a) The selection of business types should be in accordance with the skills and abilities of the KUBE cell members and in accordance with the needs of the surrounding community(s), so that marketing products/ services can be directly absorbed by consumers. This will also impact the business scope that is not only focused on the members but also the surrounding environment. For example, if the community is dominated by the tourism sector then it is better to select a business type related to the tourism sector (tour and travel, food and beverages, accessories outlet, handicraft, etc.);

b) In maintaining group cohesiveness, group leaders have a very dominant roleto play. So, in the selection of a group leader the individuals with strong leadership ability is of up most importance. This can be achieved by designing and creating a leadership assessment test to be taken by potential candidates. Yogyakarta City Government has an assessment center that can be utilized and involved in creating and conducting such a test. By involving the assessment center, a neutral test can be designed and administered with results forwarded on to the concerned department at the Social Service Center and all this can be archived at a minimal fee;

c) The need for training to improve the ability and skill of the KUBE cell members as well as Mentors is critical to achieve the desired results of the program. Cooperation with institutions that provide entrepreneurship training can be one option. This will certainly be somewhat burdensome to the government's financial budget, but this lack of adequate funds can be slightly suppressed if the government establishes cooperation with donor agencies both national and international who have concerns in the field of community empowerment or poverty alleviation;

d) Reward is a common thing in any government's program related to society. Reward is always an award in the form of appreciation for the rapid growing KUBE program and its achievement. In addition to rewards, however, punishment is required for the cells that fail to operate a business successfully; almost all social programs undertaken by the government only have rewards and no 
punishment. Punishment here means a special treatment. For example, when government operates a new program then those who have failed to run the KUBE cell program or other social programs are given the penalty for example not being able to participate in such as role for 1-2 years. This can heighten the beneficiaries though about the sustainability of programs implemented by the government. Therefore, the Yogyakarta government is expected to formulate the appropriate punishment so that in the future the beneficiaries will be more serious in carrying out the KUBE program;

e) The addition of the number of Mentors is a must. Ideally, 1 Mentor should only support a maximum of 10 groups, so as not to be overloaded. In this way, the Mentor's role can be better at transferring his knowledge on operating a new business and a problem solver for KUBE cell that he/she is attached to. Of course, the addition of the number of Mentors will require additional funds. But the addition of more Mentors is felt urgently needed because the Mentors have a very important role in the development of the KUBE cells and can be multipliers in the distillation of knowledge for several hundred; and

f) Regarding the increase officials to supervise the implementation of the KUBE program, this can be accomplished by forming a team that can come from various divisions/ departments within the local and regional governments.

\section{Reference}

Astika, Ketut Sudhana. (2010). Budaya Kemiskinan Di Masyarakat: Tinjauan Kondisi Kemiskinan Dan Kesadaran Budaya Miskin Di Masyarakat. Jurnal Ilmiah Fakultas Ilmu Sosial Dan Ilmu Politik, Vol. 1(01), pp.20-26.

BPS. (2015). Persentase Penduduk Miskin Maret 2015 Mencapai 11,22 Persen. Available at https://www.bps.go.id/pressrelease/2015/09/15/11 58/persentase-penduduk-miskin-maret-2015mencapai-11-22-persen.html [Accessed on 27 April 2017].

BPS Yogyakarta. (2017). Dinamic table of poverty. Available

https://jogjakota.bps.go.id/dynamictable/2017/07/ 10/21/kemiskinan-kota-yogyakarta.html

[Accessed on 14 September 2018].

Bruton, G. D., Ketchen Jr, D. J., \& Ireland, R. D. (2013). Entrepreneurship as a solution to poverty. Journal of Business Venturing, Vol.28(6), pp.683689.

Chambers, Robert. (1995). Poverty and Livelihoods: Whose Reality
Environment and Urbanization, Vol. 7(1), pp173204.

Mahmood, S., Hussain, J., \& Z. Matlay, H. (2014). Optimal microfinance loan size and poverty reduction amongst female entrepreneurs in Pakistan. Journal of Small Business and Enterprise Development, Vol. 21(2), pp.231-249.

Marsoyo, Agam \& Astuti, Wahyu K. (2014). The Prospect of Poor Home-based Enterprises in Yogyakarta. (proceeding), International Conference ICIAP 2 "Space for the Next Generation”, 21-22 August 2014, Gadjah Mada University (Universitas Gadjah Mada/ UGM), Yogyakarta, Indonesia

Mazmanian, Daniel A., and Paul A. Sabatier. (1983). Implementation and Public Policy. Scott Foresman and co, Dallas.

Mensah, S. A., \& Benedict, E. (2010). Entrepreneurship training and poverty alleviation: Empowering the poor in the Eastern Free State of South Africa. African Journal of Economic and Management Studies, Vol.1(2), pp.138-163.

Nazir, Mohammad. (2011). Metode Penelitian. Jakarta: Ghalia Indonesia.

Noor, Munawar et al. (2017). Institutional of Local Public Sector: Poverty Alleviation in Semarang City, Central Java, Indonesia. Int J Recent Sci Res, Vol. 8(9), pp.20203-20208.

Sahdan, Gregorius. (2005). Menanggulangi Kemiskinan Desa. Available at http://www.economirakyat.org [Accessed on 11 May 2017].

Suliswanto., dan Muhammad Sri Wahyudi. (2010). Pengaruh Produk Domestik Bruto (PDB) dan Indeks Pembangunan Manusia (IPM) Terhadap Angka Kemiskinan di Indonesia. Jurnal Ekonomi Pembangunan, Vol. 8(2), pp.357-366.

Tampubolon, J., Sugihen, B. G., Samet, M., Susanto, D., \& Sumardjo, S. (2006). Pemberdayaan Masyarakat Melalui Pendekatan Kelompok (Kasus Pemberdayaan Masyarakat Miskin melalui Pendekatan Kelompok Usaha Bersama (KUBE). Jurnal Penyuluhan, Vol. 2(2), pp. 25-32.

Utami, D. P. (2016). Dampak Sosial Ekonomi Program Penanganan Kemiskinan Melalui Kelompok Usaha Bersama (KUBE) di Bausasran Yogyakarta. Undergraduate Thesi, Fakultas Ilmu Sosial, UNY.

Yin, Robert K. (2003). Case study research, design and methods (3rd ed., vol. 5). Thousand Oaks: Sage.

Yin, R. K. (2015). Qualitative research from start to finish. Guilford Publications. New York 